\title{
Faktor-Faktor Yang Mempengaruhi Minat Mahasiswa Akuntansi Mengikuti Uskad
}

\author{
Liana Susanto \\ Yanti \\ Viriany \\ Henny Wirianata \\ Universitas Tarumanagara \\ lianas@fe.untar.ac.id
}

\begin{abstract}
:
The purpose of this research was to obtained empirical evidence about the influence of subjective norms, behavioral control, and expectations for the results of the interest of accounting students to take USKAD. Samples were taken by purposive sampling technique. Data were obtained through questionnaires. Respondents in this research were 2015 and 2016 Faculty of Economics Tarumanagara University accounting students. Data from the questionnaires were processed using the Smart-PLS program version 3.2.8. The results of the research showed subjective norms, behavioral control, and expectations for the results have significant influence towards the interest of accounting students to take USKAD.
\end{abstract}

Keywords: uskad, interest of accounting students.

\section{PENDAHULUAN}

Masyarakat Ekonomi Asean yang terbentuk di Asia Tenggara menyebabkan persaingan semakin ketat di berbagai bidang termasuk di bidang jasa akuntansi (Widyanto dan Fitriana, 2016). Akuntan dituntut untuk memiliki keahlian dan kompetensi yang handal di bidangnya. Salah satu cara untuk meningkatkan keahlian dan kompetensi seorang akuntan adalah dengan menempuh ujian sertifikasi akuntansi yang diakui secara nasional, regional dan international. Di Indonesia, Ikatan Akuntan Indonesia (IAI) adalah lembaga profesi akuntan yang memiliki tanggung jawab untuk meningkatkan pengetahuan dan keahlian masyarakat di bidang akuntansi. Ada beberapa ujian 
program sertifikasi yang diadakan IAI, diantaranya: Ujian Sertifikasi Ahli Akuntansi Pemerintahan (USAAP), Ujian Sertifikasi Chartered Accountant (USCA), Ujian Sertifikasi Akuntansi Syariah (USAS), dan Ujian Sertifikasi Keahlian Akuntansi Dasar (USKAD). USKAD pertama kali diadakan pada tahun 2013. USKAD adalah ujian untuk mengukur keahlian peserta dalam empat hal. Pertama, untuk memahami dan menjelaskan kerangka dasar penyusunan dan penyajian laporan kuangan sesuai dengan standar akuntansi keuangan (SAK). Kedua, untuk mengidentifikasikan transaksitransaksi yang terdapat dalam laporan keuangan. Ketiga, untuk menyusun dan menyajikan laporan keuangan sesuai dengan siklus akuntansi. Terakhir, untuk melakukan analisa dasar laporan keuangan (www.iaiglobal.or.id). Ikatan Akuntan Indonesia (IAI) memberikan dua persyaratan untuk mengikuti USKAD. Pertama, ijazah peserta harus minimal setingkat SMA atau SMK sederajat dari semua jurusan dibuktikan dengan copy ijazah yang telah dilegalisir. Kedua, peserta adalah mahasiswa aktif jurusan akuntansi atau pendidikan akuntansi serta vokasi program studi akuntansi (www.iaiglobal.or.id). Ada beberapa teori yang dapat digunakan dalam mengukur minat seseorang, salah satu diantaranya adalah Teori Perilaku Terencana (Theory of Planned Behavior -TPB). Teori ini dicetuskan oleh Icek Ajzen di tahun 1985 melalui tulisannya yang berjudul "From intentions to actions: A theory of planned behavior". Teori ini telah berhasil menjelaskan faktor-faktor yang mendorong perilaku seseorang. Dalam penelitian ini diharapkan teori ini mampu menjelaskan minat mahasiswa akuntansi mengikuti USKAD (Dharmawan, 2017). Beberapa penelitian yang pernah dilakukan untuk menguji minat mahasiswa akuntansi tingkat S1 untuk mengikuti berbagai ujian sertifikasi selain USKAD adalah: Sumaryono (2016) yaitu minat mahasiswa mengikuti Ujian Sertifikasi Chartered Accountant, Permata, dkk. (2012) yaitu yaitu minat mahasiswa mengikuti Ujian Sertifikasi Akuntan Syariah (USAS), Novitasari dan Suwaldiman (2017) yaitu minat mahasiswa mengikuti sertifikasi Association of Chartered Certified Accountant, Susanti dkk. (2015) yaitu minat mahasiswa mengikuti Pendidikan Profesi Akuntansi, dan Arisman (2016) 
yaitu kesadaran mahasiswa mengikuti

\section{TELAAH LITERATUR}

Teori Perilaku Terencana (Theory of Planned Behavior/ TPB). Menurut Ajzen dan Driver (1991), Theory of Planned Behavior (TPB) adalah perkembangan dari Theory of Reasoned Action (TRA) yang mana tujuan dari teori tersebut adalah untuk memprediksi serta menjelaskan niat dan juga perilaku seseorang. Menurut TRA, ada dua hal yang menentukan niat seseorang yaitu sikap seseorang dan norma subjektif. Selanjutnya dalam TPB ditambahkan satu lagi faktor yang menentukan niat seseorang yaitu perceived behavioral control. Tujuan ditambahkannya kontrol perilaku persepsian ini ke dalam TPB menurut Chau dan Hu (Hartono, 2007) adalah untuk mengontrol perilaku individual yang dibatasi oleh keterbatasan serta kekurangan dari sumber daya untuk melakukan perilaku. Menurut Ajzen (2005), asumsi dari TPB adalah bahwa sikap akan berpengaruh terhadap niat untuk berperilaku, tetapi sikap bukanlah penentu perilaku secara langsung dan harus dikombinasikan dengan norma subjektif dan kontrol perilaku persepsian. sertifikasi profesi.

Teori Kognitif Sosial (Social Cognitive Theory/SCT).

Teori ini dikembangkan oleh Bandura pada tahun 1977. Teori kognitif sosial ini merupakan sebuah teori yang mempelajari tentang perilaku dari individu. Menurut Bandura (1986) dalam Mukhid (2009), dasar daripada teori kognitif sosial adalah suatu pandangan mengenai human agency. Human agency ini dimaksudkan bahwa seorang individu adalah merupakan agen yang proaktif ikut serta di dalam lingkungan mereka serta dapat menyebabkan sesuatu terjadi dengan adanya tindakan yang mereka lakukan. Menurut Compeau dan Higgins (Hartono, 2007) model yang didasarkan pada teori kognitif sosial ini suatu hubungan yang saling berkaitan dari tiga hal yaitu faktor lingkungan, faktor kognitif (individu), dan faktor perilaku. Faktor lingkungan mencakup suatu dorongan dari orang lain, penggunaan oleh orang lain serta dukungan. Faktor kognitif mencakup efikasi diri serta harapan akan hasil. Efikasi diri merupakan kepercayaan 
mengenai kemampuan dari seorang individu dalam melakukan sebuh perilaku tertentu. Faktor ketiga yaitu faktor perilaku yang mencakup perasaan, kecemasan, serta pemanfaatan. Dapat disimpulkan bahwa dalam teori kognitif sosial ini niat seseorang untuk melakukan sesuatu dipicu karena dua hal yaitu efikasi diri serta harapan akan hasil.

Minat. Menurut Nurhayani (2012) yang dimaksud dengan minat adalah suatu kecenderungan hati yang tinggi terhadap sesuatu atau dapat dikatakan merupakan gairah ataupun keinginan. Pengertian lain mengenai minat dikemukakan oleh Susanti, et al (2015) yang menyatakan bahwa minat adalah suatu sikap yang positif terhadap aspekaspek lingkungan. Disamping itu minat juga dapat dikatakan sebagai suatu kecenderungan yang tetap dalam hal untuk memperhatikan serta menikmati suatu aktivitas tertentu yang disertai dengan perasaan yang senang.

Menurut Widyastuti, et al (2004), minat adalah keinginan yang dipengaruhi setelah seseorang melihat, mengamati, membandingkan, dan juga mempertimbangkan sesuai dengan kebutuhannya. Selain itu minat juga merupakan suatu kecenderungan hati yang tinggi akan sesuatu. Ada beberapa hal terkait dengan minat yang perlu untuk menjadi perhatian yaitu:

a. Minat menunjukkan berapa kuatnya seseorang berani untuk mencoba melakukan suatu hal.

b. Minat juga dapat menggambarkan seberapa banyak usaha yang telah dilakukan oleh seseorang dalam merencanakan sesuatu.

c. Minat dipandang sebagai faktor motivasional yang mempunyai pengaruh terhadap suatu perilaku.

\section{Norma Subjektif}

Norma subjektif adalah adalah persepsi seseorang mengenai tekanan sosial untuk melakukan atau tidak melakukan suatu perilaku. Perilaku seseorang tergantung niat, kemudian niat dalam berperilaku tergantung dari sikap (attitude) dan norma subyektif. Di sisi lain, keyakinan terhadap perilaku dan evaluasi akan menentukan perilaku (Ajzen, 1991). Hartono (2007) berpendapat bahwa norma subjektif merupakan suatu pandangan seseorang akan kepercayaan orang lain yang nantinya akan berpengaruh terhadap minat untuk melakukan ataupun untuk tidak melakukan sesuatu perilaku yang sedang dipertimbangkan. 
Kontrol Perilaku

Ajzen (1991) menganggap kontrol perilaku dipengaruhi oleh dua keyakinan yaitu control beliefs dan control power. Control beliefs adalah keyakinan tentang keberadaan hal-hal yang mendukung atau menghambat perilaku yang akan dilakukan. Sedangkan control power adalah persepsi individu tentang seberapa kuat hal-hal yang mendukung dan menghambat dalam berperilaku. Seseorang akan cenderung untuk melakukan suatu perilaku jika orang tersebut lebih merasakan adanya faktor yang mendukung daripada faktor yang menghambat untuk bisa melakukan sebuah perilaku. Begitu pula sebaliknya jika seseorang merasa lebih banyak faktor yang menghambat dibandingkan dengan faktor yang mendukung, maka orang tersebut akan menganggap dirinya sulit dalam melakukan suatu perilaku tertentu. Menurut Hartono (2007), kontrol perilaku merupakan suatu kesulitan ataupun suatu kemudahan dalam melakukan suatu perilaku dan juga dapat diartikan sebagai persepsi ataupun konstrukkonstruk baik internal maupun eksternal dari suatu perilaku.
Harapan Atas Hasil.

Harapan akan hasil merupakan keyakinan (harapan) dalam melakukan perilaku tertentu. Seseorang akan mengharapkan hasil-hasil dari perilaku yang diambil (Hartono, 2007). Susilowati (2012) berpendapat bahwa tujuan seseorang dapat dipengaruhi oleh harapan akan hasil. Selanjutnya, usaha untuk merealisasikan tujuan tersebut akan mempengaruhi niat seseorang. Ini dapat menolong seseorang pada saat memilih pekerjaan di dalam banyak kesempatan kerja yang mana pada saat itu orang tersebut tidak mudah untuk mendapatkan pekerjaan yang diinginkan.

Pengaruh Norma Subjektif Terhadap Minat Mahasiswa Akuntansi Mengikuti USKAD.

Penelitian Sumaryono menemukan bahwa faktor pihak referan memiliki pengaruh terhadap minat mahasiswa mengikuti ujian sertifikasi CA . Faktor referan antara lain orang tua, teman, keluarga dan dosen. Apabila pihak referan mendukung maka semakin tinggi niat mahasiswa mengikuti ujian sertifikasi CA. Dharmawan (2017) juga mendukung 
kesimpulan ini dan menemukan bahwa norma subjektif berpengaruh signifikan positif terhadap minat mahasiswa mengikuti USKAD. Atas dasar ini maka dirumuskan hipotesis pertama yaitu :

$\mathrm{H}_{1}$ : Norma subjektif berpengaruh signifikan positif terhadap minat mahasiswa mengikuti USKAD.

Pengaruh Kontrol Perilaku Terhadap Minat Mahasiswa Akuntansi Mengikuti USKAD.

Penelitian Sumaryono menyimpulkan bahwa kontrol perilaku memiliki pengaruh terhadap niat mahasiswa mengikuti ujian sertifikasi CA (Chatered Accountant). Apabila ada faktor-faktor yang memudahkan maka niat mengikuti ujian sertifikasi akan makin tinggi dan sebaliknya apabila ada faktor-faktor yang menyulitkan maka niat mengikuti ujian sertifikasi akan makin rendah. Hal ini sejalan dengan penelitian Dharmawan (2017) yang menyimpulkan bahwa kontrol perilaku memiliki pengaruh terhadap niat mahasiswa mengikuti USKAD. Hipotesis kedua dirumuskan sebagai berikut:

$\mathrm{H}_{2}$ : Kontrol Perilaku berpengaruh signifikan positif terhadap minat mahasiswa mengikuti USKAD.

Pengaruh Harapan Terhadap Hasil Terhadap Minat Mahasiswa Akuntansi Mengikuti USKAD.

Semakin tinggi harapan terhadap hasil maka minat untuk melakukan sesuatu akan semakin tinggi. Hal ini dibuktikan oleh Law (2010) yang menyatakan bahwa harapan atas hasil berpengaruh signifikan posistif terhadap minat. Hipotesis yang dikembangkan adalah:

$\mathrm{H}_{3}$ : Harapan terhadap hasil berpengaruh signifikan positif terhadap minat mengikuti USKAD model dalam penelitian ini dapat digambarkan sebagai berikut:

Gambar 1 Model Penelitian

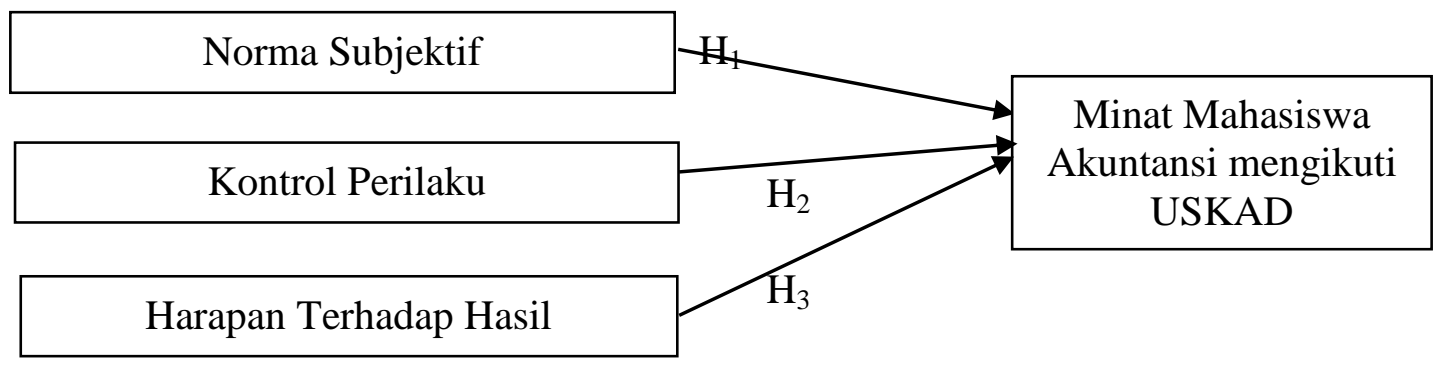




\section{METODOLOGI PENELITIAN}

Populasi dan Sampel.

Populasi dari penelitian ini adalah para mahasiswa akuntansi Universitas Tarumanagara. Metode pengambilan sampel adalah purposive sampling dengan kriteria mahasiswa akuntansi angkatan 2015 dan 2016. Operasionalisasi Variabel Penelitian. Variabel dependen dalam penelitian ini adalah minat mahasiswa akuntansi mengikuti USKAD (Y), sedangkan norma subjektif $\left(\mathrm{X}_{1}\right)$, kontrol perilaku $\left(\mathrm{X}_{2}\right)$, serta harapan akan hasil $\left(\mathrm{X}_{3}\right)$ adalah variabel independen. Variabel norma subjektif diproksikan dengan tiga pertanyaan, variabel kontrol perilaku diproksikan dengan tiga pertanyaan, variabel harapan akan hasil diproksikan dengan enam pertanyaan, serta variabel minat mahasiswa akuntansi mengikuti USKAD diproksikan dengan dua pertanyaan. Tabel 1 dan 2 dibawah ini memperlihatkan operasionalisasi variabel dalam penelitian ini. Seluruh variabel diukur menggunakan skala likert dengan diberi angka satu sampai lima

Tabel 1. Operasionalisasi Variabel

\begin{tabular}{c|l}
\hline \multicolumn{1}{c|}{ Variabel } & \multicolumn{1}{c}{ Indikator } \\
\hline \multirow{2}{*}{ Norma Subjektif $\left(\mathrm{X}_{1}\right)$} & Orang tua saya berpikir bahwa saya harus mengikuti USKAD \\
\cline { 2 - 2 } & Dosen saya mendorong saya untuk mengikuti USKAD \\
\cline { 2 - 2 } & $\begin{array}{l}\text { Sebagian besar teman saya mendorong saya mengikuti } \\
\text { USKAD }\end{array}$ \\
\hline Kontrol Perilaku $\left(\mathrm{X}_{2}\right)$ & Saya mempunyai waktu untuk belajar materi USKAD \\
\cline { 2 - 2 } & $\begin{array}{l}\text { Saya memiliki fasilitas atau kemudahan untuk mendukung } \\
\text { USKAD }\end{array}$ \\
\cline { 2 - 2 } & Saya tahu bagaimana mempersiapkan USKAD \\
\hline
\end{tabular}


Tabel 2. Operasionalisasi Variabel

\begin{tabular}{l|l}
\multicolumn{1}{c}{ Variabel } & \multicolumn{1}{|c}{ Indikator } \\
\hline \multirow{2}{*}{$\begin{array}{l}\text { Harapan akan hasil } \\
\left(\mathrm{X}_{3}\right)\end{array}$} & Memiliki sertifikasi USKAD lebih kompetitif di pasar kerja \\
\cline { 2 - 2 } & $\begin{array}{l}\text { Memiliki sertifikasi USKAD mengurangi kemungkinan } \\
\text { diberhentikan dari pekerjaan }\end{array}$ \\
\cline { 2 - 2 } & Memiliki sertifikasi USKAD menghasilkan lebih banyak uang \\
\cline { 2 - 2 } & $\begin{array}{l}\text { Memiliki sertifikasi USKAD mendorong kematangan dalam } \\
\text { berkarir }\end{array}$ \\
\cline { 2 - 2 } & $\begin{array}{l}\text { Memiliki sertifikasi USKAD mendorong kematangan dalam } \\
\text { intelektual }\end{array}$ \\
\cline { 2 - 2 } $\begin{array}{l}\text { Minat mahasiswa } \\
\text { akuntansi mengikuti } \\
\text { USKAD (Y) }\end{array}$ & Saya berniat mengikuti USKAD \\
\cline { 2 - 2 } & Saya mempunyai ide/gagasan untuk mengikuti USKAD \\
\hline
\end{tabular}

Teknik Pengumpulan Data.

Data dalam penelitian ini merupakan data primer yang dikumpulkan dengan menyebarkan kuesioner. Responden yang merupakan mahasiswa akuntansi diminta untuk menjawab 14 pertanyaan yang ada di tabel 1. Responden dalam penelitian ini adalah mahasiswa akuntansi Universitas Tarumanagara angkatan 2015 dan 2016.
Teknik Pengolahan Data.

Pengolahan data menggunakan program

Partial Least Modeling (Smart-PLS)

versi 3.2.8. Uji statistik yang dilakukan adalah uji outer dan inner model. Uji outer dilakukan untuk menguji validitas dan reliabilitas. Uji inner dilakukan untuk menguji model dan hipotesis penelitian. Model regresi dalam penelitian ini adalah sebagai berikut:

$$
\mathrm{Y}=\alpha+\beta 1 \mathrm{X}_{1}+\beta 2 \mathrm{X}_{2}+\beta 3 \mathrm{X}_{3}+e
$$

Keterangan:

$\mathrm{Y}=$ Minat mahasiswa akuntansi mengikuti USKAD

$\alpha \quad=$ Konstanta

$\mathrm{X}_{1} \quad=$ Norma subjektif

$\mathrm{X}_{2}=$ Kontrol perilaku

$\mathrm{X}_{3}=$ Harapan akan hasil

e $=$ Error 
Pengujian Model Pengukuran (Outer Model). Pengujian Model Pengukuran (Outer Model, sering juga disebut outer relation atau measurement model) menunjukkan bagaimana variabel yang diobservasi diukur (Hair et al, 2011).

Uji validitas.

Uji validitas konvergen (Convergent Validity) berhubungan dengan prinsip bahwa pengukur-pengukur (manifest variable) dari suatu konstruk seharusnya berkorelasi tinggi. Indikator refleksif dapat dilihat dari nilai loading factor untuk tiap indikator konstruk. Aturan praktis yang digunakan untuk menilai convergent validity yaitu nilai loading factor harus lebih besar dari 0,7 untuk penelitian bersifat confirmatory dan nilai loading factor antara 0,6 - 0,7 untuk penelitian yang bersifat exploratory masih dapat diterima. Namun untuk penelitian tahap awal dari pengembangan skala pengukuran nilai loading factor 0,5 - 0,6 sudah dianggap cukup (Chin, 1998). Metode lain untuk mengukur convergent validity adalah dengan Average Variance Extracted (AVE), jika nilai AVE dari masingmasing variabel memiliki nilai di atas 0,5 maka telah memenuhi kriteria convergent validity (Hair et al, 2011).
Uji Validitas Diskriminan (Discriminant Validity) berhubungan dengan prinsip bahwa pengukurpengukur (manifest variabel) konstruk yang berbeda seharusnya tidak berkorelasi dengan tinggi. Discriminant validity diukur dari nilai cross loadings dari setiap indikator dan sesuai dengan kriteria Fornell-Larcker yaitu nilai akar kuadrat AVE setiap konstruk harus lebih besar dari korelasi antar konstruk. Discriminant Validity dianggap valid jika nilai loadings dari masing-masing indikator memiliki nilai lebih besar dari nilai loadings variabel lainnya (Hair et al, 2011).

Uji Reliabilitas

Uji reliabilitas dilakukan untuk membuktikan akurasi, konsistensi dan ketepatan instrumen dalam mengukur konstruk. Terdapat cara untuk mengukur reliabilitas yaitu dengan composite reliability 46 (DillonGoldstein's). Untuk menilai reliabilitas konstruk yaitu nilai composite reliability harus lebih besar dari 0,7. Apabila seluruh nilai variabel laten memiliki nilai composite reability sebesar 0,7, berarti konstruk memiliki reabilitas yang baik atau kuesioner yang digunakan sebagai alat dalam penelitian 
ini telah andal atau konsisten (Hair et al, 2011). Pengujian Model Struktural. Uji model struktural dilakukan untuk melihat kuat tidaknya suatu hubungan antar variabel di dalam model tersebut dan juga untuk menguji hipotesis yang telah dirumuskan pada penelitian dapat "ditolak" atau "tidak ditolak" (Hair et $a l, 2011)$. Kriteria yang harus terpenuhi dalam analisis model struktural antara lain:

Pengujian Hipotesis.

Hair et al (2011) menyatakan bahwa pengujian hipotesis dalam suatu penelitian dengan menggunakan metode analisis PLS-SEM dapat dilakukan dengan melihat nilai t-statistic yang terdapat pada analisis jalur antar variabel (path analysis) melalui metode bootstrapping. Untuk menguji hipotesis dalam penelitian ini dapat dilakukan dengan membandingkan nilai $t$-statistic dengan batas minimum 1,96 $(\propto=5 \%)$. Terdapat dua kemungkinan hasil yang dapat terjadi pada hipotesis penelitian, yaitu: Hipotesis penelitian ditolak apabila nilai $t$-statistic pada model penelitian ini lebih kecil dari 1,96 (tstatistics < 1,96) atau hipotesis diterima apabila nilai $t$ statistic lebih besar dari 1,96 .
Uji Goodness of Fit Model.

Dalam menguji nilai ketepatan sebuah model dengan PLS dapat dilihat dari Normed Fit Index (NFI). Goodness of Fit Index (GoF Index) dikembangkan untuk mengevaluasi model pengukuran dan model struktural dan disamping itu menyediakan pengukuran sederhana untuk keseluruhan dari prediksi model. GoF Index dihitung dari akar kuadrat nilai average communality index dan average $R$-square. Nilai NFI berkisar dari nol sampai satu. Semakin mendekati 1 model dikatakan semakan fit (Ghozali, 2014).

Uji Koefisien Determinasi.

Untuk menilai model dengan PLS dapat dilihat dari nilai $R$-Square. Perubahan nilai $R$-square dapat digunakan untuk menjelaskan pengaruh variabel laten independen tertentu terhadap variabel laten dependen apakah mempunyai pengaruh yang substantif. Nilai dari koefisien determinanasi $\left(\mathrm{R}^{2}\right)$ memiliki nilai yang berada diantara 0 sampai dengan 1 , nilai koefisien determinasi dikelompokkan menjadi 0,75:0,5 dan 0,25 untuk variabel laten dapat dijelaskan sebagai pengaruh substansial, moderat dan lemah (Hair et al, 2011). Analisis Data. Data dalam penelitian ini diperoleh dari 108 kuesioner dengan 
rincian seperti pada Tabel 3 dan Tabel 4.

karakteristik responden diuraikan dalam

Tabel 3. Rincian Kuesioner

\begin{tabular}{ll}
\multicolumn{1}{c}{ Kuesioner } & \multicolumn{1}{c}{ Jumlah } \\
Kuesioner yang disebar & 130 kuesioner \\
Kuesioner yang kembali & 109 kuesioner \\
Kuesioner yang diisi dengan tidak lengkap & 1 kuesioner \\
Kuesioner yang dipakai dalam penelitian & 108 kuesioner \\
\hline \multicolumn{2}{c}{ Sumber: (Data diolah, 2019) }
\end{tabular}

Sumber: (Data diolah, 2019)

Tabel 4. Karakteristik Responden

\begin{tabular}{|c|c|c|}
\hline Karakteristik & Jumlah & Persentase \\
\hline \multicolumn{3}{|l|}{ Jenis Kelamin } \\
\hline Pria & 21 & $19 \%$ \\
\hline Wanita & 87 & $81 \%$ \\
\hline \multicolumn{3}{|l|}{ Usia } \\
\hline$<20$ tahun & 53 & $49 \%$ \\
\hline 20-30 tahun & 55 & $51 \%$ \\
\hline \multicolumn{3}{|l|}{ Semester } \\
\hline 4 & 75 & $70 \%$ \\
\hline 6 & 32 & $30 \%$ \\
\hline \multicolumn{3}{|c|}{ Pernah mendengar USKAD } \\
\hline Pernah & 16 & $15 \%$ \\
\hline Tidak & 92 & $85 \%$ \\
\hline \multicolumn{3}{|l|}{ Minat USKAD } \\
\hline $\mathrm{Ya}$ & 81 & $75 \%$ \\
\hline Tidak & 27 & $25 \%$ \\
\hline
\end{tabular}

Sumber: (Data diolah, 2019)

Hasil Uji Validitas.

Uji validitas yang akan digunakan adalah dengan menggunakan

Convergent Validity dan Discriminant Validity, dengan hasil

(1) Uji Validitas Konvergen (Convergent Validity).

Tabel 5. Hasil Analisis Average Variance Extracted (AVE)

\begin{tabular}{lc}
\multicolumn{1}{c}{ Variabel } & Average Variance Extracted $(\boldsymbol{A} \boldsymbol{V E})$ \\
Harapan akan Hasil & 0.621 \\
Kontrol Perilaku & 0.676 \\
Minat & 0.841 \\
Norma Subjektif & 0.67 \\
\hline
\end{tabular}

Sumber: (Data diolah, 2019) 
Hasil analisis convergent validity dalam penelitian ini diuraikan pada Tabel 5 di atas. Convergent validity mengukur sejauh mana suatu instrumen pengukur secara positif berhubungan dengan instrumen pengukur lainnya yang digunakan untuk mengukur suatu konstruk yang sama. Gambar 2 di bawah ini adalah diagram loading factor masing-masing indikator dalam penelitian.

Gambar 2. Hasil Analisis Validitas Konvergen

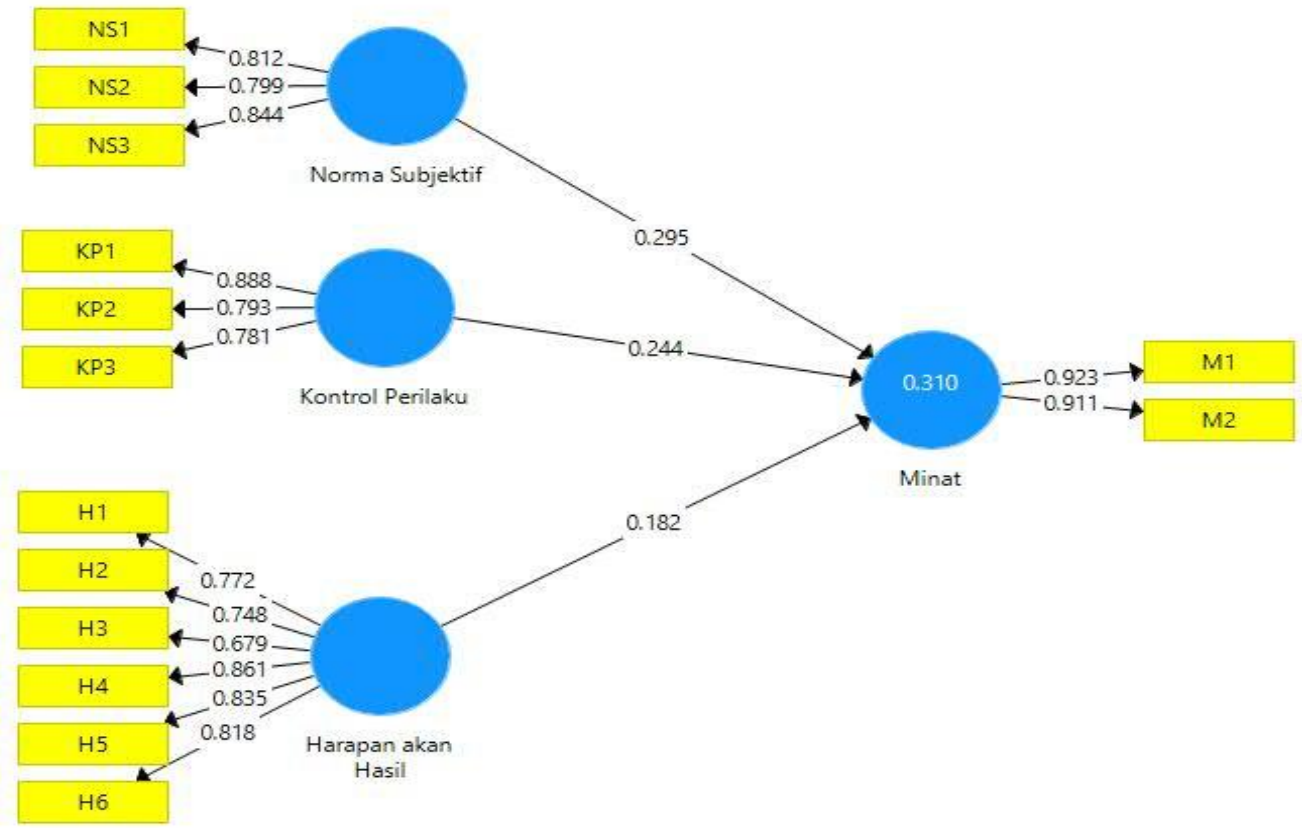

(2) Uji Validitas Diskriminan (Discriminant Validity).

Hasil Uji Validitas Diskriminan dengan cross loading disajikan pada Tabel 6 . Berdasarkan Tabel 6, dapat diketahui bahwa nilai loading factor dari masingmasing indikator setiap variabel lebih besar dari pada nilai loading factor variabel lainnya. Hal ini menunjukkan bahwa indikator-indikator tersebut telah memenuhi kriteria discriminant validity yang diukur dari nilai cross loadings. Tabel 7 merupakan hasil analisis nilai Fornell-Larcker untuk setiap variabel. Berdasarkan Tabel 7 dapat diketahui nilai akar kuadrat AVE setiap variabel lebih besar dari korelasi antar variabel sehingga memenuhi kriteria FornellLarcker. Hal ini menunjukkan bahwa variabel-variabel tersebut memenuhi discriminant validity. 
Tabel 6. Hasil Nilai Cross Loadings

\begin{tabular}{ccccc} 
Harapan akan & Kontrol Perilaku & Minat & $\begin{array}{c}\text { Norma } \\
\text { Subjektif }\end{array}$ \\
H1 & 0.772 & 0.235 & 0.263 & 0.277 \\
H2 & 0.748 & 0.299 & 0.272 & 0.254 \\
H3 & 0.679 & 0.232 & 0.136 & 0.172 \\
H4 & 0.861 & 0.254 & 0.333 & 0.277 \\
H5 & 0.835 & 0.146 & 0.237 & 0.207 \\
H6 & 0.818 & 0.288 & 0.312 & 0.179 \\
KP1 & 0.231 & 0.888 & 0.473 & 0.375 \\
KP2 & 0.253 & 0.793 & 0.296 & 0.427 \\
KP3 & 0.308 & 0.781 & 0.285 & 0.472 \\
M1 & 0.333 & 0.471 & 0.923 & 0.402 \\
M2 & 0.296 & 0.346 & 0.911 & 0.462 \\
NS1 & 0.211 & 0.391 & 0.417 & 0.812 \\
NS2 & 0.253 & 0.316 & 0.256 & 0.799 \\
NS3 & 0.261 & 0.485 & 0.434 & 0.844 \\
\hline
\end{tabular}

Sumber: (Data diolah, 2019)

Tabel 7. Hasil Analisis Fornell-Lacker

\begin{tabular}{lcccc} 
Harapan akan & $\begin{array}{c}\text { Kontrol } \\
\text { Perilaku }\end{array}$ & Minat & $\begin{array}{c}\text { Norma } \\
\text { Subjektif }\end{array}$ \\
Harapan akan Hasil & 0.788 & & & \\
Kontrol Perilaku & 0.31 & 0.822 & & \\
Minat & 0.344 & 0.448 & 0.917 & \\
Norma Subjektif & 0.293 & 0.499 & 0.47 & 0.819 \\
\hline & Sumber: (Data Diolah, 2019)
\end{tabular}

Hasil Uji Reliabilitas

Tabel 8. Hasil UJi Composite Reliability

\begin{tabular}{l|c} 
& Composite Reliability \\
\hline Harapan akan Hasil & 0.907 \\
\hline Kontrol Perilaku & 0.862 \\
\hline Minat & 0.914 \\
\hline Norma Subjektif & 0.859 \\
\hline \multicolumn{2}{|c}{ Sumber: Data diolah, 2019 }
\end{tabular}


Reliabilitas adalah "a test of how consistenly a measuring instrument measures whatever concept it is measuring" (Sekaran \& Bougie, 2013). Analisis reliabilitas dilakukan dengan memperhatikan nilai Composite Reliability dari variabel-variabel dalam penelitian seperti yang ditunjukkan pada Tabel 8 di atas. Tabel 7

\section{HASIL DAN PEMBAHASAN}

Uji Inner model dilakukan untuk melihat kuat tidaknya suatu hubungan antar variabel di dalam model penelitian menunjukkan bahwa nilai Composite Reliability untuk semua konstruk adalah diatas 0,7 yang menunjukkan bahwa semua konstruk pada model ini diperkirakan memenuhi kriteria uji reliabilitas (Hair et al, 2011). Uji Reliabilitas menunjukkan bahwa variabel $X_{1}, X_{2}, X_{3}$ dan $Y$ memenuhi uji reliabilitas.

dan juga untuk menguji hipotesis yang telah dirumuskan pada penelitian apakah "ditolak" atau "tidak ditolak" (Hair et al, 2011). Tahapan pengujian inner model adalah sebagai berikut:

Hasil Uji Hipotesis

Tabel 9. Hasil Bootstrapping

\begin{tabular}{lccc} 
& $\begin{array}{c}\text { Original } \\
\text { Sample }(\boldsymbol{O})\end{array}$ & $\begin{array}{c}\text { T Statistics } \\
(\mid \boldsymbol{O} / \text { STDEV } \mid)\end{array}$ & $\boldsymbol{P}$ Values \\
Harapan akan Hasil -> Minat & 0.182 & 2.307 & 0.021 \\
Kontrol Perilaku -> Minat & 0.244 & 2.333 & 0.02 \\
Norma Subjektif -> Minat & 0.295 & 3.125 & 0.002 \\
\hline
\end{tabular}

Sumber: Data diolah, 2019

Berdasarkan hasil dari Tabel 9 dapat dilihat bahwa nilai statistik untuk semua variabel menunjukkan angka di atas 1,96 yang artinya variabel norma subjektif, kontrol perilaku dan harapan akan hasil berpengaruh signifikan terhadap variabel minat mahasiswa mengikuti USKAD. Nilai t statistik dari variabel norma subjektif adalah 3.125 (>1.96), dan nilai original sampel adalah 0.295 yang artinya bahwa variable norma subjektif berpengaruh signifikan positif terhadap minat mahasiswa mengikuti USKAD sehingga $\mathrm{H}_{1}$ diterima. Nilai $\mathrm{t}$ statistik dari variabel control perilaku adalah 2.333 
(>1.96), dan nilai original sampel adalah 0.244 yang artinya bahwa variabel kontrol perilaku berpengaruh signifikan positif terhadap minat mahasiswa mengikuti USKAD sehingga $\mathrm{H}_{2}$ diterima. Nilai $\mathrm{t}$ statistik dari variabel harapan atas hasil adalah 2.307
(>1.96), dan nilai original sampel adalah 0.812 yang artinya bahwa variabel harapan akan hasil berpengaruh signifikan positif terhadap minat mahasiswa mengikuti USKAD sehingga $\mathrm{H}_{3}$ diterima.

Hasil Uji Goodness of Fit

Tabel 10. Hasil Uji NFI

\begin{tabular}{cc} 
& Saturated Model \\
NFI & 0,662 \\
\hline
\end{tabular}

Sumber: Data diolah, 2019

Untuk menilai ketepatan sebuah model dengan PLS dapat dilihat dari NFI. Nilai NFI mendekati 1 mengisyaratkan model yang diuji memiliki ketepatan

Hasil Uji Koefisien Determinasi

Koefisien determinasi digunakan untuk mengetahui seberapa besar kontribusi variabel-variabel independen yang terdiri dari norma subjektif, control perilaku dan minat atas hasil untuk yang baik (Ghozali, 2014). Hasil dari Uji NFI dapat dilihat pada Tabel 9 di atas yang menunjukkan nilai NFI sebesar 0,662.

memprediksi variabel dependen pada penelitian ini yaitu minat untuk mengikuti USKAD. Hasil akan ditampilkan dalam Tabel 10 di bawah ini.

Tabel 11. Hasil Analisis Koefisien Determinasi atau $\mathrm{R}_{2}$

\begin{tabular}{lc} 
& \multicolumn{2}{c}{ R Square } \\
Minat & 0,31 \\
\hline Sumber: Data diolah, 2019
\end{tabular}

Berdasarkan hasil pengujian koefisien determinasi yang disajikan pada Tabel 10 di atas, dapat diketahui nilai $\mathrm{R}$ square adalah sebesar 0,31 yang berarti bahwa sebesar $31 \%$ dari variabel dependen yaitu minat mengikuti 
USKAD dapat dijelaskan oleh variabelvariabel yang terdapat dalam penelitian ini dan sisanya yaitu sebesar $69 \%$ $(100 \%-31 \%)$ dijelaskan oleh variabelvariabel di luar penelitian ini.

\section{SIMPULAN}

Penelitian ini bertujuan untuk mendapatkan bukti empiris pengaruh norma subjektif, kontrol perilaku dan harapan atas hasil terhadap minat mahasiswa mengikuti USKAD. Hasil penelitian menunjukkan bahwa variabel norma subjektif, kontrol perilaku, dan harapan atas hasil berpengaruh signifikan terhadap minat mahasiswa mengikuti USKAD.

\section{DAFTAR PUSTAKA}

Ajzen, L \& driver, B.L. (1991).

Prediction of leisure Participation From Bahavioural, normative, and control beliefs : An Application of the Theory of Planned Behaviour. Leisure Sciences, 13, 185-204

Ajzen, I. (2005). Attitude Personality and Behaviour 2nd. New York : Open University PresArmitage, C. J., \& Corner, M. 2001. Efficacy of the Theory of Planned Behaviour : A Metaanalytic review. British Journal
Berdasarkan pendapat yang dikemukakan oleh Hair et al. (2011) maka nilai $\mathrm{R}$ square dalam penelitian ini tergolong moderat.

Berdasarkan kesimpulan di atas dapat disampaikan beberapa saran untuk penelitian berikutnya. Responden dalam penelitian dapat diperbanyak dengan menyebarkan kuesioner di universitas lain. Selain itu, pada penelitian selanjutnya dapat menambah variabel lain seperti sikap responden terhadap minat mahasiswa mengikuti USKAD.

of Social Psychology, 40, 471499

Arisman, R. (2016). Kesadaran

Mahasiswa Akuntansi Terhadap Sertifikasi Profesi. Universitas Islam Indonesia.

Chin, W. W. (1998). The Partial Least Squares Approach to Structural Equation Modeling. Modern Methods for Business Research, 295-336. 
Dharmawan, Y. (2017). Analisis Faktor

Pendorong Niat Mahasiswa Diploma III Akuntansi Untuk Mengikuti Ujian Sertifikasi Keahlian Akuntansi Dasar (USKAD). KIA IV. ISBN 987602-70083-4-2. Universitas Pancasila. Jakarta.

Ghozali, I. (2014). Structural Equation

Modeling, Metode Alternatif dengan Partial Least Square (PLS). Edisi 4. Semarang : Badan Penerbit Universitas Diponegoro.

Hartono,J. (2007). Sistem Informasi

Keperilakuan. Edisi Revisi. Yogyakarta: Andi Offset.

Hair, J. F., Ringle, C. M., \& Sarstedt, M. (2011). PLS-SEM: Indeed a Silver Bullet. Journal of Marketing Theory and Practice, 19 (2), 139-152. DOI 10.2753/MTP1069-6679190202.

Law, P. K. (2010). A Theory of

Reasoned Action Model of Accounting Students Career Choice in Public Accounting Practices in The Post Enron. Emerald Insight. https://doi.org/10.1108/0967542 1011050036

Mukhid, A. (2009). Self Efficacy:

Perspektif Teori Kognitif Sosial dan Implikasinya terhadap Pendidikan. Jurnal Tadrîs. 4 (1). 106-122.

Novitasari, Diyah dan Suwaldiman.

(2017). Faktor-Faktor yang Mempengaruhi Mahasiswa Prodi Akuntansi FE UII Untuk Mengambil Program Sertifikasi ACCA. Prosiding Seminar
Nasional Multi Disiplin Ilmu dan Call for Paper Unisbank.

Nurhayani, U. (2012). Pengaruh

Motivasi terhadap Minat Mahasiswa Akuntansi untuk Mengikuti Pendidikan Profesi Akuntansi (PPAk). Jurnal Mediasi. 4 (1).

Permata Ulfah, Mafudi, dan Ratu A. S.,

(2012). Faktor yang Dipertimbangkan Mahasiswa Untuk Mengikuti Ujian Sertifikasi Akuntansi Syariah. Jurnal Solusi. 11(1). 1-18.

Priyatno, D. (2012). Cara Kilat Belajar

Analisis Data dengan SPSS 20, Edisi 1. Yogyakarta: ANDI.

Sumaryono, \& Sukanti. (2016). FaktorFaktor yang Mempengaruhi Niat Mahasiswa Akuntansi untuk Mengambil Sertifikasi Chartered Accountant. Profita.

Susanti, S., H.M. Rasuli, dan Al Azhar L, (2015). Faktor-Faktor yang Mempengaruhi Minat Mahasiswa Akuntansi untuk Mengikuti Pendidikan Profesi Akuntansi (PPAk) pada Perguruan Tinggi di Pekanbaru. JOM Fekon. 2(1). 1-15

Susilowati, N. (2012). Sikap Mahasiswa terhadap Undang-Undang Akuntan Publik pada Optimisme dan Perencanaan Karir. Simposium Nasional Akuntansi. 
Wardani, G. A. S., \& Januarti, I. (2015). Niat Untuk Mengambil Chartered Accountant dengan Theory of Planned Behavior. Jurnal Akuntansi \& Auditing.

Widyastuti, S.W.et al (2004). Pengaruh Motivasi Terhadap Minat Mahasiswa Akuntansi Untuk Mengikuti Pendidikan Profesi
Akuntansi (PPAk), Simposium Nasional Akuntansi VII Bali

Widyanto, Eko A. dan Rahmawati

Fitriana. (2016). Pengaruh Motivasi Terhadap Minat Mengikuti Ujian Chartered Accountant (CA) Indonesia. Jurnal Eksis. $12 \quad$ (1). 